\title{
DEFERMENT OF A.S.T.P. TEACHERS
}

The following is a copy of an undated notice sent through Service Commands to presidents of institutions participating in or scheduled to participate in the Army Specialized Training Program. It is not known as yet whether the instructions given therein are modified or altered by the provisions of LBM 115-B.

\section{NOTICE CONCERNING DEFERMENT OF ASTP TEACHERS}

\section{(Sent through Service Commands)}

To Presidents of Institutions Participating in or Scheduled to Participate in the Army Specialized Training Program:

It is of the utmost importance that qualified and irreplaceable teachers who are at institutions under contract to the Army Specialized Training Program and who are providing instruction under the program be permitted to continue this work.

The requirements of the Army Specialized Training Program indicate that very serious disruption is probable if the responsible officials of these institutions do not sufficiently emphasize to Selective Service Authorities the necessity for the occupational deferment of these teachers.

As a first step, it is requested that all teachers in institutions under contract to the Army Specialized Training Program register their qualifications with the National Roster of Scientific and Specialized Personnel, Washington, D. C. The National Roster is concerned with the proper utilization of professional personnel and is an important source of information in this matter to the Selective Service System.

The Selective Service Form 42-A, completely filled out, should be used for individual teachers for whom deferment is considered necessary, to furnish the appropriate local board with specific information reflecting the considered judgment of the institution with respect to qualifications, degree of training, and experience required to engage in the profession; and to inform the board either (1) that no replacement can be obtained and that replacement training time is too great to afford relief, or (2) that no replacement can be obtained immediately, in which case the time required for replacement should be indicated. Special attention should be devoted to furnishing complete information concerning the capacities and duties of the individual teacher. In cases where teachers can be replaced, it should be emphasized that the replacement should not break into the term during which the incumbent teacher is giving instruction.

It is essential that all possible means of procuring replacement be employed, including the transfer of non-vulnerable teachers who are engaged in civilian training, the conversion of teachers from cognate fields or from administrative duties, the recruitment of teachers not now engaged in essential activities, and in general the maximum practical use of existing teaching personnel.

Where deferment is not obtained at the local board level, appeal should be made within ten days to the area or district appeals board and if necessary the case should be called to the attention of the State Director with a request for a Presidential appeal. 
You are requested to adhere strictly to all Selective Service procedures regarding occupational deferment. You are also requested to advise the Military Commandant of your institution immediately when any irreplaceable teacher is classified by Selective Service authorities as available for military service.

In the event that the Military Commandant at the institution considers the deferment of the teacher to be essential to the success of the Army Specialized Training Program, representations to that effect may be made by him to the State Director of the Selective Service System. Such representations are not to be made, however, unless all appeal procedure provided under the Selective Service Act is being pursued and unless in fact the particular teacher is irreplaceable in the institution.

In the event that the deferment is denied after all appeal steps through the state level have been complied with, the institution should immediately transmit the matter to the Labor Branch, Industrial Personnel Division, Headquarters, Army Service Forces, for representations at the Washington level.

In the case of the irreplaceable teacher whose induction into the Army has taken place, causing serious jeopardy to the Army Specialized Training Program, institutions may submit a full statement of the facts to the Labor Branch, Industrial Personnel Division, Headquarters, Army Service Forces, Washington, D. C., for consideration of methods for remedial action. 